\title{
Determining Karst Transmissivities with Inverse Modeling and an Equivalent Porous Media
}

\author{
by M. Larocque ${ }^{a, b}$, O. Banton ${ }^{b}$, P. Ackererc ${ }^{c}$ and M. Razack ${ }^{a}$
}

\begin{abstract}
Flow simulation is difficult to implement in heterogeneous media such as karst aquifers, primarily because the structure of the rock is extremely complex and usually unknown. The aim of this study was to verify the possibility of using inverse modeling and an equivalent porous media to identify transmissivities in a slightly karstified aquifer, the La Rochefoucauld karst (Charente, France). Different simulation scenarios were tested: using two spatial discretizations with different finite-element cell sizes and using measured or interpolated heads. The inverse modeling was performed with the downscaling parameterization procedure, using a finite-element representation of bidimensional ground water flow. The inverse modeling converged satisfactorily with all scenarios: head residuals were small and spring flow rates and the river/aquifer exchanges were adequately simulated. The scenario using small cells and measured heads generated a highly heterogeneous transmissivity field, indicating an overparameterization of the problem. The calibrated transmissivities and simulated heads of this scenario proved less reliable overall than those of the other scenarios. The use of interpolated heads generated more uniform transmissivities as a result of the head smoothing. A rotation of the initial parameter mesh showed that the scenarios using interpolated heads generate the most stable and reliable results. The scenarios with interpolated heads could therefore be used when head measurements are limited or are unevenly distributed over the aquifer. Overall, the calibrated transmissivities reproduced the entire range of transmissivities measured in the field using different methods. The results indicate that inverse modeling and an equivalent porous media can be used to determine transmissivities in a moderately karstified aquifer.
\end{abstract}

\section{Introduction}

Simulation is a useful tool for planning ground water use. However, flow simulation is difficult to implement in heterogeneous media such as karst aquifers, primarily because the structure of the rock is extremely complex and usually unknown. Karst aquifers include a wide variety of more or less karstified limestone from the less developed or slow flow aquifers to the highly localized or rapid flow aquifers (White 1969; Atkinson 1977). When the carbonate rocks have not undergone much dissolution and when the objective of the modeling is to represent regional flow for management purposes, a model using an equivalent porous media can be a reasonable approximation of reality (Ford and Williams 1989). This type of model has been used successfully by different authors in moderately karstified carbonate aquifers (Pulido-Bosch and PadillaBenitez 1988; Kresic et al. 1990; Estrela and Sahuquillo 1997; Angelini and Dragoni 1997).

The calibration of hydraulic properties is a crucial step in ground water modeling. Automatic inverse modeling is now widely

aLaboratory of Hydrogeology, UMR CNRS 6532, Université de Poitiers, 40 ave. Recteur Pineau, 86022 Poitiers Cedex, France.

bINRS-Eau, Université du Québec, 2800 Einstein, CP 7500, SteFoy, Qué., Canada, G1V 4C7. E-mail: larocque@inrs-eau.uquebec.ca (first author).

'Institut de Mécanique des Fluides de Strasbourg, UMR 7507 Université Louis Pasteur-CNRS, 2, rue de Boussingault, 67000 Strasbourg, France.

Received August 1998, accepted June 1999. used for this purpose as a rapid and objective alternative to manual calibration (Yeh and Mock 1996). Automatic calibration is helpful in resolving large systems and is becoming recognized as a necessary tool in ground water modeling (Poeter and Hill 1997). However, only a limited number of inverse modeling studies have attempted to identify flow parameters in heterogeneous media (e.g., Zhang and Bai 1996). Most of the applications of an equivalent porous media in karst environments have used only spring flow rates and a limited number of head data to manually calibrate the model. However, such a simple calibration does not guarantee that the spatial distribution of heads, i.e., the transmissivity field over the aquifer, is correctly simulated. In fact, a greater number of hydraulic measurements results in a more representative calibrated transmissivity field. The main objective of this study was to examine the level of detail in the transmissivity field that can be determined from measured heads in a karst aquifer with inverse modeling and an equivalent porous media. A second objective was to determine the influence of the calculation cell size and head interpolation on the results. The La Rochefoucauld Aquifer (Charente, France), a karst aquifer for which a large number of measured head data are available, is used as a field application. The studied aquifer is first presented, followed by the selected inverse modeling procedure. Finally, the results, including the identified transmissivities, are reviewed and discussed.

\section{The La Rochefoucauld Karst Aquifer}

The La Rochefoucauld Aquifer covers more than $600 \mathrm{~km}^{2}$ (Figure 1), east of the city of Angoulême (Charente, France). Its main 


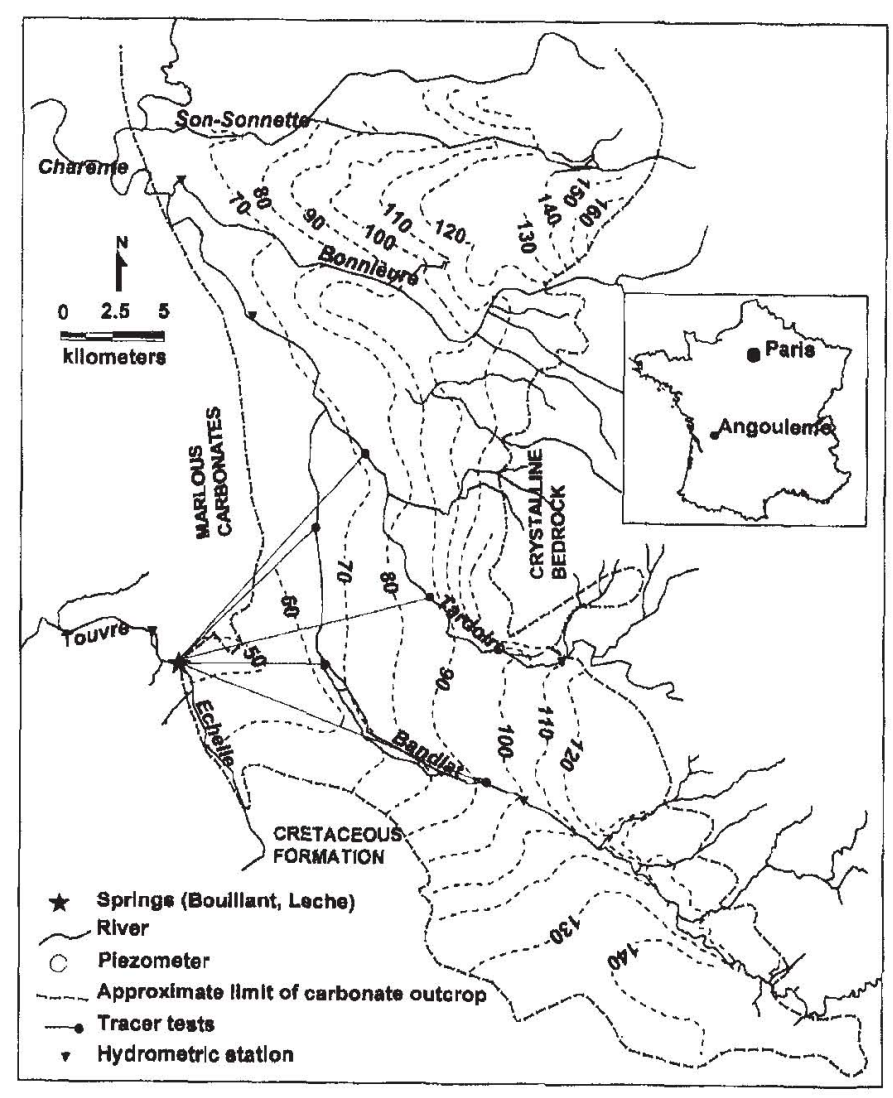

Figure 1. The La Rochefoucauld karst aquifer.

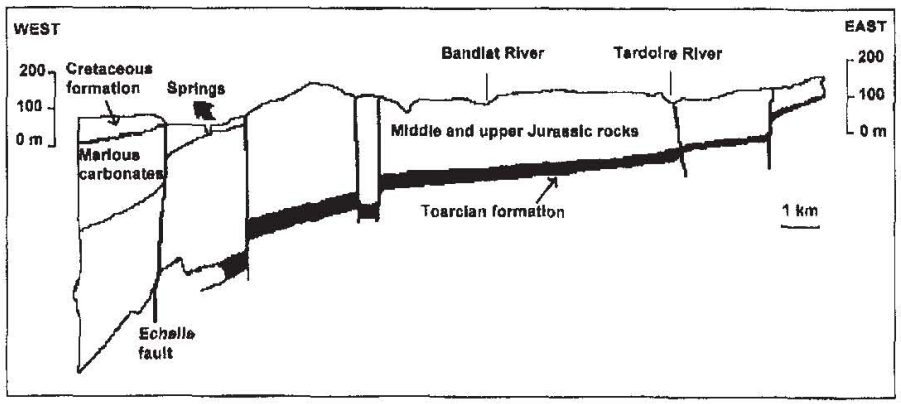

Figure 2. Geology of the karst aquifer (adapted from Rouiller 1987).

spring is used by the city of Angouleme for water supply, and the ground water is used regionally for irrigation. The perennial outlet, with an average flow rate of $12.8 \mathrm{~m}^{3} / \mathrm{s}$, is the second most important spring in France after the Fontaine de Vaucluse. Because the aquifer is set in karstic rocks, is globally unconfined, and has a thin soil cover, it is highly vulnerable to pollution. Thus, local authorities have undertaken various studies to gain a better understanding of the aquifer in order to manage and protect the resource.

To the east, the aquifer begins where the sedimentary rocks cover the crystalline bedrock (Massif central; Figures 1 and 2). The aquifer is in middle and upper Jurassic rocks. It is boarded on the west side by a thick, semipervious series of marlous carbonates along faults and flexures. The aquifer is underlain by the impervious Toarcian formation.

The main discharge from the aquifer is the perennial Bouillant spring. A secondary discharge point, the Leche spring, is nearby. Along with the Echelle River, these springs are the main perennial water input to the Touvre River. The Bandiat and Tardoire rivers are sinking streams recharging the carbonate aquifer. These rivers dry out every summer as they flow over the carbonate rocks. Their water losses constitute more than half of the average flow from the springs. The Bonnieure and Echelle rivers are perennial and flow over the northern part and near the southwestern limit of the domain, respectively.

Water levels were measured at numerous locations in the aquifer at the end of March 1994 (Hydro-Invest 1994) following a high water period during which the flow rates at the springs were relatively constant. Heads were measured from unused wells for which elevations were estimated from topographic maps (the measurement error is estimated to be approximately $1 \mathrm{~m}$ ). It is assumed that every measured head represents the average water level over a vertically homogeneous aquifer. At the regional scale, the water levels (Figure 1) appear to be continuous and hydraulic gradients are relatively homogeneous throughout the aquifer. Hydrometric stations downstream from the springs on the Touvre River, upstream on the Bandiat and Tardoire rivers, and downstream on the Tardoire and Bonnieure rivers provide river flow rate information.

The aquifer is characterized by important ground water level fluctuations over time, sharp flow rate variations at the springs, and also numerous stream sinks. Tracer tests performed between river losses and the springs (Figure 1) have shown that water speeds can reach 50 to $100 \mathrm{~m} / \mathrm{h}$ locally (Quelennec et al. 1971). These observations indicate the presence of localized dissolution channels conducting rapid flow. On the other hand, the study of recession curves has shown that the slow component of the flow is also important (Rouiller 1987). Results from correlation and spectral analyses (Larocque et al. 1998) have shown that the aquifer has a large storage capacity and empties slowly. The impulse response of the aquifer is approximately 76 days. For comparison, Mangin (1984) found impulse responses of 14, 23, 50, and 70 days for karst aquifers in the French Pyrenees, the last one believed to have considerable storage and little karstification. Pumping tests were performed on the La Rochefoucauld karst aquifer at different locations over the aquifer and have shown that the aquifer generally behaves (at least locally) like an equivalent porous media. Because of its flow behavior (importance of the slow component of the flow, long impulse response, Theis-Jacob behavior to pumping tests), an equivalent porous media has been used for the modeling. The overall flow is then simulated without taking into consideration the dual component of flow in the fractured matrix and the dissolution channels.

Piezometric data show that the eastern contact with the crystalline bedrock constitutes an imposed flux boundary during the recharge period (i.e., from November to February inclusively). The northern and southern limits correspond to piezometric crests (Figure 1) and are set as no-flow boundaries. The western and southwestern limits correspond to faults closing the aquifer around the springs and are also set as no-flow boundaries. The upper part of the carbonate rock is probably the most transmissive because it is more karstified. However, not enough data were available to determine the thickness of this more transmissive layer and the entire thickness of the carbonate rocks was set as transmissive material. It varies in depth from $20 \mathrm{~m}$ (eastern limit) to $550 \mathrm{~m}$ (near the springs).

Both springs are represented as a constant head (elevation $47 \mathrm{~m}$ ). Larocque et al. (1998) have shown that the Echelle River does not contribute to the springs and it is therefore excluded from the model. Drainage to the aquifer from the Tardoire, Bandiat, and 
Bonnieure rivers is considerable. The calculation of the river/aquifer leakage requires an evaluation of the surface and bottom of the rivers as well as the exchange coefficients. The first two values were measured in the field while the exchange coefficients for the Tardoire and Bandiat rivers were calibrated manually. The information needed for the calibration of these parameters was obtained from the hydrometric stations upstream on each river and from the one station downstream from their confluence on the Tardoire River. The calibration could not be carried out for the Bonnieure River due to the absence of an upstream hydrometric station.

\section{The Inverse Modeling Procedure}

A steady-state simulation was performed for the high water period of February to March 1994. During this period, the flow rates at the springs were almost constant and the ground water flow was considered to be at a steady state. The heads measured at the end of March 1994 were used to calibrate the model. Larocque et al. (1998) have shown that there is an average delay of about one month (from 10 to 61 days) between a precipitation event and a variation of the piezometric heads. To integrate this transmission delay, the net recharge for the steady-state simulation was calculated using precipitation and evapotranspiration data for the month preceding the head measurements. The net recharge was calculated using a water budget in a superficial layer of $1 \mathrm{~m}$ of soil having an available water capacity of $0.1 \mathrm{~m}$. Evapotranspiration occurs freely in this reservoir until it is empty; then the evapotranspiration feeds on the monthly precipitation. When the reservoir is full, excess water generates infiltration and recharge to the aquifer. This simulation method assumes that the unsaturated carbonate rock does not play a significant role in infiltration. Different authors in karst environments (Pulido-Bosch and Padilla-Benitez 1988; Jeannin and Grasso 1995; Estrela and Sahuquillo 1997) have used it. The calculated net recharge for the month preceding the head measurements amounts to $3.6 \mathrm{~mm} /$ day (using the net recharge over the entire impulse response, i.e., two months, yields almost the same value). Water uptake from the aquifer is composed of a limited number of drinking water pumping wells $\left(0.05 \mathrm{~m}^{3} / \mathrm{s}\right)$ and many irrigation pumping wells $\left(0.28 \mathrm{~m}^{3} / \mathrm{s}\right)$. Since irrigation occurs mainly from June to August, it was not included in the simulation.

The inverse modeling procedure was performed to calibrate transmissivities and imposed fluxes using the downscaling parameterization procedure developed at the Institut de Mécanique des Fluides of the Université de Strasbourg (Siegel 1995; Chardigny et al. 1996; Siegel et al. 1996). The method uses the HPP-GMS finite-element ground water flow model (Blaschke et Blöschl 1992) to simulate bidimensional ground water flow.

The inverse modeling procedure requires the minimization of an objective function. Here, the objective function is composed of two terms: the sum of the squared differences between the measured and the simulated heads, and a regularizing term that reduces the oscillations of the calibrated parameters. The regularizing term smoothes the calibrated transmissivity field. The objective function is minimized iteratively using a quasi-Newton algorithm. The gradient of the objective function is calculated analytically using the adjoint state method (Chavent 1974). The BFGS method (Byrd et al. 1995) is used to approximate the Hessian of the objective function. With this mathematical scheme, the number of parameters estimated can be greater than the number of measured heads. This combination of mathematical techniques makes the selected approach efficient and reliable.
In distributed models, the transmissivity must be discretized to create a parameter vector on which the calibration is performed. This procedure, also called the parameterization of the model, is an important step in inverse modeling. According to Yeh (1986), the dimension of the parameter vector should be related to the quality and quantity of the measured heads. In practice, the number of observations is limited and they often contain some error. Reducing the number of parameters through parameterization improves the wellposedness of the problem (existence of a unique solution and stability in a neighborhood around the solution). In the downscaling parameterization procedure, the hydraulic conductivities are described with a parameter mesh that is independent of the computation finite-element mesh. The hydraulic conductivity distribution is first defined using only four elements, and is large enough to include the entire system. This forms the parameter mesh. Transmissivities are calibrated at the nodes of this initial parameter mesh and the transmissivities required for the computation mesh are interpolated linearly. When convergence is attained (i.e., the objective function remains constant and/or the gradient of the objective function is small, which usually occurs rapidly with the initial parameter mesh), each parameter cell is divided into four cells and the calibration is performed again on all the nodes using previous values as the initial parameter set. This downscaling procedure goes on until the calibration criterion is met or until the size of the parameter mesh equals the size of the computation mesh. This multiscale parameterization technique adapts the aquifer discretization to the information provided by the measured heads and ensures the regularization of the parameter distribution.

The size of the computation mesh is important for two reasons: First, each cell should be large enough to take into account the local heterogeneity of the aquifer; second, in the downscaling procedure, the mesh refinement can be performed until the size of the parameter mesh equals that of the computation mesh. Therefore, the smaller the computation mesh, the more the parameters can be adjusted. In some cases, this may result in a better fit, but it can also lead to a less reliable transmissivity field that is based on an insufficient number of measured heads, as the ratio between the measured heads and the estimated parameters decreases. To investigate this aspect of the calibration, two finite-element meshes were used, with maximum cell lengths of $1 \mathrm{~km}$ and $2.5 \mathrm{~km}$, respectively.

The spatial repartition of the heads used in the calibration can have a significant impact on the results. Measured heads are not homogeneously distributed over the aquifer, particularly in the southeastern corner and north of the springs. The areas where more heads are available are more constrained, leading to a more reliable transmissivity calibration. To evaluate the impact of the measured heads, the transmissivities were calibrated in two steps. First, the calibration was performed using heads measured on the aquifer at the end of March 1994. Seventy measured calibration heads were used with the large cells and 117 measured calibration heads were used with the small cells. The calibration was also performed using regularly spaced interpolated heads obtained by kriging the measured values. Ordinary kriging (Delhomme 1976) was performed under the intrinsic hypothesis using a moving neighborhood assuming that the head increment is stationary. Fifty-four interpolated calibration heads were used for both mesh sizes. Figure 3 illustrates the models with the two cell sizes and the two reference head scenarios. 
a) large cells

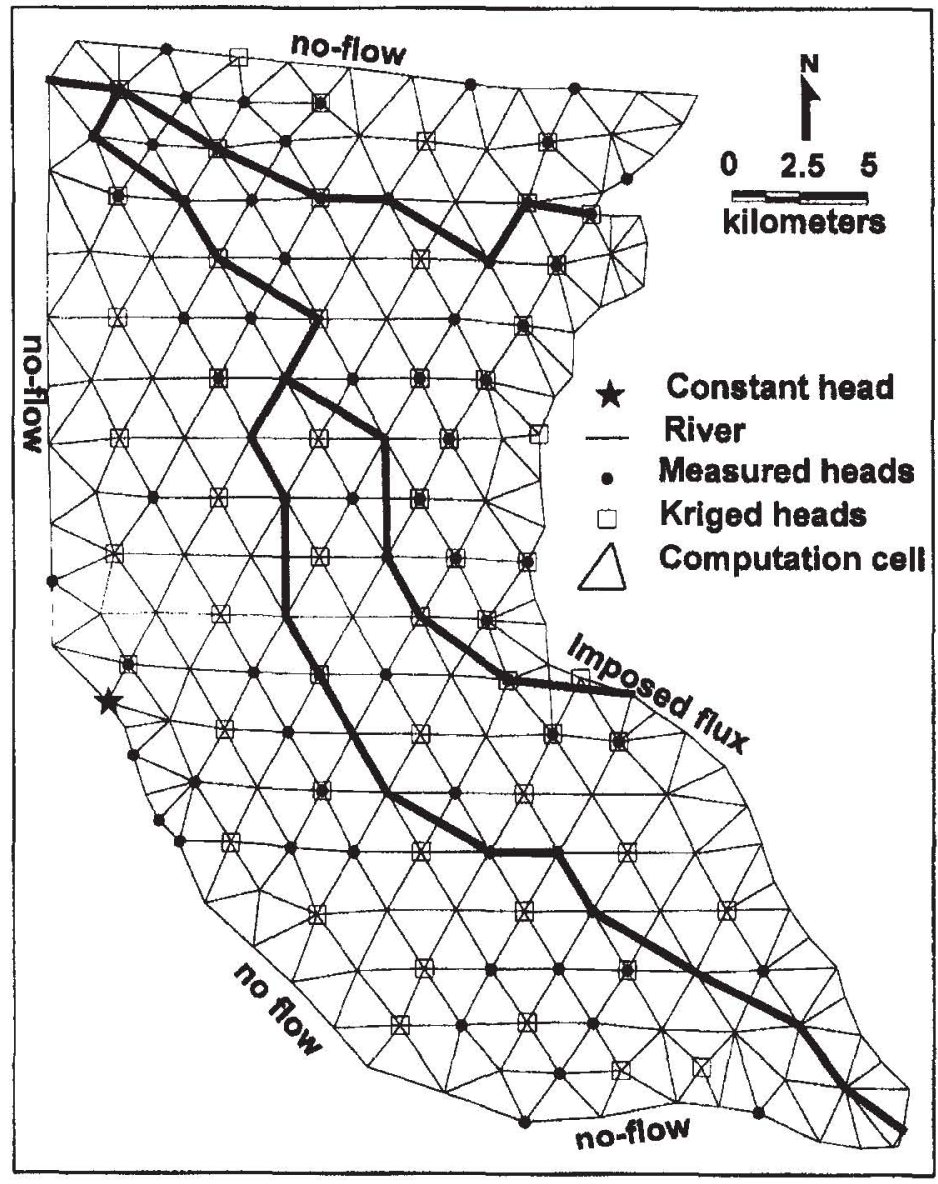

b) small cells

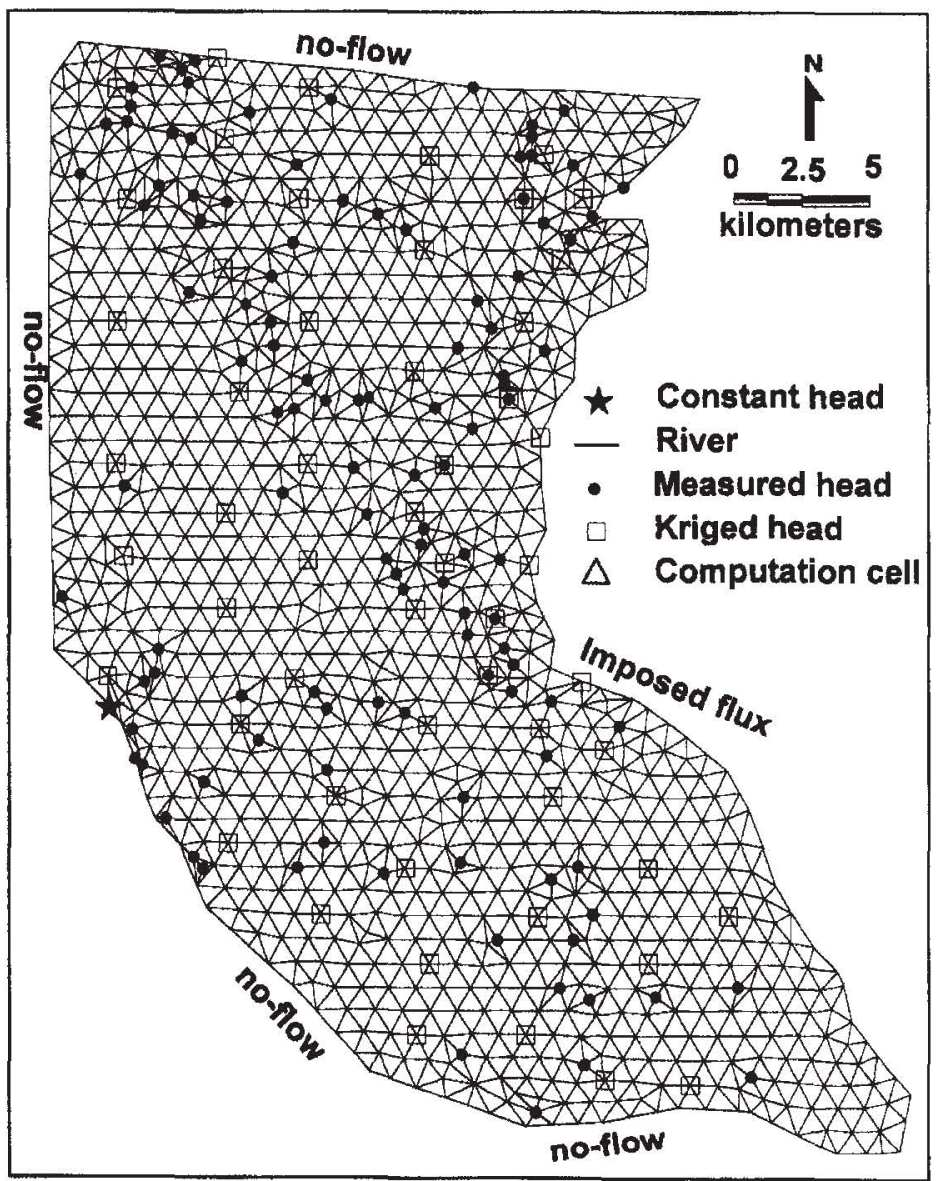

Figure 3. Model of the La Rochefoucauld karst aquifer: (a) large cells; (b) small cells.

Table 1

Calibration Results (Optimal Orientation of the Initial Parameter Mesh)

\begin{tabular}{|c|c|c|c|c|c|c|c|}
\hline $\begin{array}{l}\text { Cell } \\
\text { Size }\end{array}$ & $\begin{array}{l}\text { Reference } \\
\text { Heads }\end{array}$ & $\begin{array}{c}\text { Head } \\
\text { Residuals } \\
(\mathrm{m})\end{array}$ & $\begin{array}{c}Q \\
\text { Springs } \\
\left(\mathrm{m}^{3} / \mathrm{s}\right)\end{array}$ & $\begin{array}{c}\mathrm{Q} \\
\text { Bandiat } \\
\left(\mathrm{m}^{3} / \mathrm{s}\right)\end{array}$ & $\begin{array}{c}Q \\
\text { Tardoire } \\
\left(\mathrm{m}^{3} / \mathrm{s}\right)\end{array}$ & $\begin{array}{c}Q \\
\text { Bonnieure } \\
\left(\mathrm{m}^{3} / \mathrm{s}\right)\end{array}$ & $\begin{array}{c}\text { Imposed } \\
\text { Fluxes } \\
\left(\mathrm{m}^{3} / \mathrm{s}\right)\end{array}$ \\
\hline Large & Measured & $-0.0059 *(1.16)^{* *}$ & 23.93 & 6.11 & 0.95 & -0.43 & 0.12 \\
\hline Large & Kriged & $-0.044(0.21)$ & 23.25 & 8.58 & -2.11 & -0.43 & 0.22 \\
\hline Small & Measured & $-0.0022(0.19)$ & 24.91 & 3.58 & 3.11 & -0.20 & 0.20 \\
\hline Small & Kriged & $-0.00013(0.0019)$ & 25.17 & 6.63 & -0.25 & -0.72 & 0.12 \\
\hline \multicolumn{3}{|c|}{ Field measurements } & 22.15 & \multicolumn{2}{|c|}{6.62} & & \\
\hline
\end{tabular}

*Average value.

**Standard deviation.

\section{Results}

The determination coefficients $\left(r^{2}\right)$ between the measured and the simulated heads are all equal to one (as a result of the calibration procedure), and the average head residuals are small and not significantly different from zero (t-test, $\alpha=0.05$ ). The standard deviations of the head residuals are of the same order of magnitude as the head measurement errors (Table 1). This similarity attests to the satisfactory convergence of the inverse modeling. When using the inverse modeling with the large cells and both head scenarios or with the small cells and the measured heads, the downscaling was performed until the size of the parameter mesh reached the size of the computation mesh. This procedure required three and four cell refinements for the large and small cells, respectively. The scenario using the small cells and the interpolated heads was refined only twice. This lesser refinement could be due to the smoothing of the data inherent to the interpolated heads and is an indication that the use of small cells is superfluous with interpolated heads. 


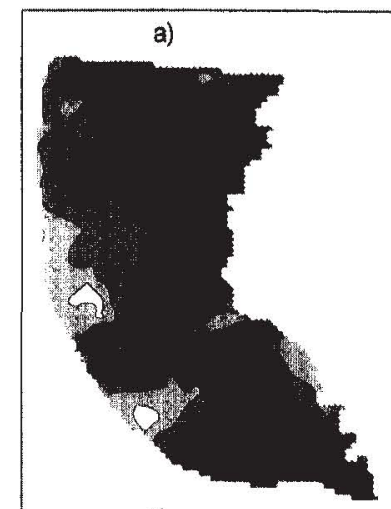

c)

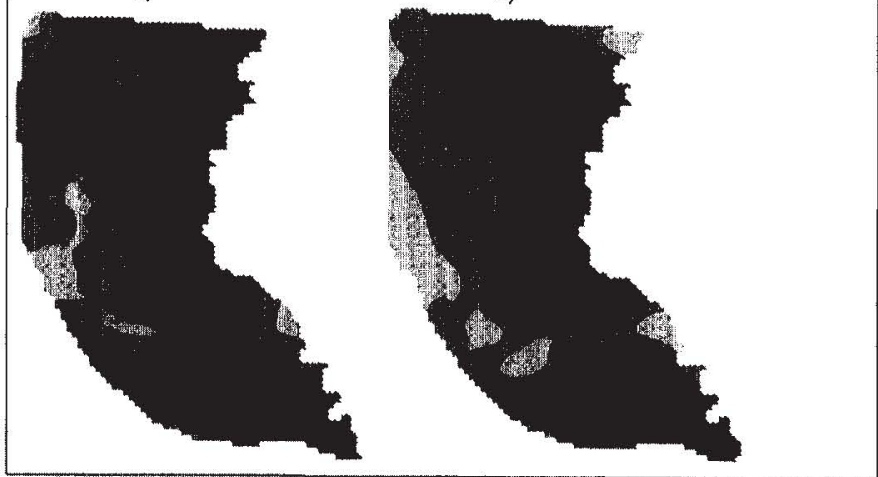

Figure 4. Calibrated transmissivity fields: (a) large cells, measured heads; (b) small cells, measured heads; (c) large cells, kriged heads; (d) small cells, kriged heads.

The steady-state spring flow rates are slightly overestimated. This discrepancy could be related to the simple method used to calculate the recharge that may overestimate this flow component. In reality, the unsaturated carbonate rock probably also contributes to the regulation of infiltration, reducing direct recharge to the ground water. The exchange coefficients were adjusted manually to simulate river/aquifer exchanges. With the interpolated heads, the river/aquifer exchanges are in favor of the Tardoire River (negative flow rates), while the opposite is true when the simulation is done with the measured heads. In the absence of a measurement station on the Bandiat River before its confluence with the Tardoire, it was impossible to verify which reference head scenario is the most appropriate. The Bonnieure River drains part of the aquifer (negative flow rates), mostly in its downstream section. This behavior corresponds to the measured piezometric heads (Figure 1). However, the exchanged fluxes could not be calibrated on the Bonnieure River because of the absence of an upstream measurement station on this river. The calibrated imposed fluxes on the eastern limit are relatively small, but they are required to simulate heads in this area of the aquifer. It was not possible to verify which scenario is the most realistic. Nevertheless, these results indicate that the calibrated model adequately represents the measured flows with the hypotheses intrinsic to the equivalent porous media.

Another important result of inverse modeling is the calibrated transmissivity field. The four calibrated transmissivity fields (Figure 4) show an increase of transmissivity from east to west that can be related to the increasing thickness of the aquifer and to the development of the drainage network toward the outlet. Transmissivity values can be high, especially in the vicinity of the springs, representing the combined influence of both fractures and drains. The calibrated transmissivity range is greater when using measured heads.

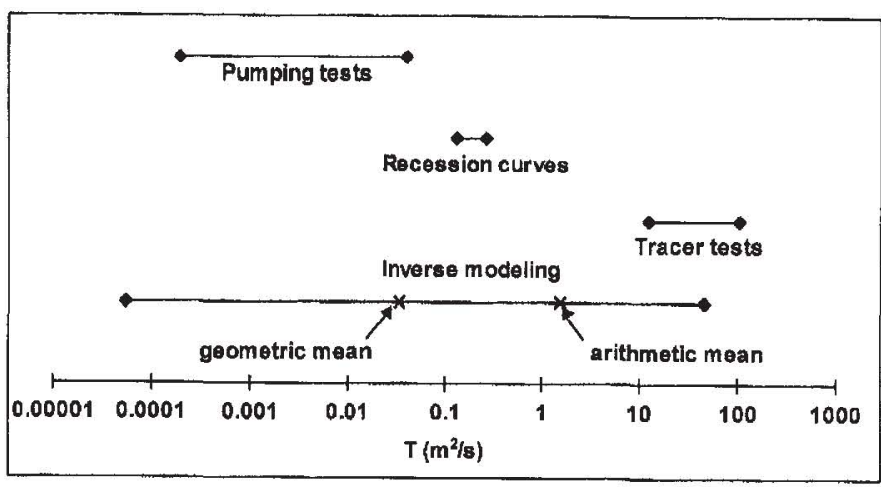

Figure 5. Comparison of transmissivities obtained using different techniques.

This difference is attributable to the local variability present in the measured heads. Moreover, the use of interpolated heads generates little transmissivity contrast because the heads have been smoothed by kriging. With the measured heads, the inverse modeling identified significant local transmissivity contrasts. However, these contrasts do not form any linear pattern that could be associated with the presence of drains. The local transmissivity contrasts are more important with small cells. This may be related to the large size of the parameter vector in comparison with the head vector that could induce an overparameterization of the model when using small cells.

Field-measured transmissivity values were obtained from aquifer pumping tests (Theis-Jacob interpretation), recession curves (method of Atkinson 1977), and tracer tests (assuming that the tracer injected in river sinks travels in karstic conduits). Figure 5 compares these values with the calibrated transmissivities. The calibrated transmissivities cover a wide range of values that are consistent with field measurements. The low calibrated transmissivities are similar to those obtained from the aquifer pumping tests that show the equivalent porous media behavior of the aquifer. The calibration therefore agrees with the transmissivity measurements in areas where karstification is limited and where an equivalent porous media can represent the fractured rock. The mean calibrated transmissivities are close to the transmissivities obtained from recession curves. This is understandable since recession curves represent the global influence of all parts of the aquifer (more and less karstified). The highest transmissivities are similar to those determined from tracer tests conducted between river sinks and the springs, and which correspond to fast conduit flow. These high calibrated transmissivity values are found close to the springs and identify the potential flowpaths followed by the tracers (Figure 1). This comparison of transmissivity values shows that there is enough information in the measured heads for the inverse method to adequately reproduce the range of transmissivities observed in the field.

The downscaling approach produces a unique transmissivity map for each scenario. However, a rotation of the initial parameter mesh provides a different transmissivity map and there are as many solutions to the calibration as there are initial parameter mesh positions. To verify the influence of the initial position of the parameter mesh on the results, it was rotated by 2.5 degrees from 0 to 90 degrees. Calibrations of the transmissivities and the imposed fluxes were performed for each new position of the initial parameter mesh. The results provide an estimate of the uncertainty associated with the calibrated parameters and its impact on the simulated 


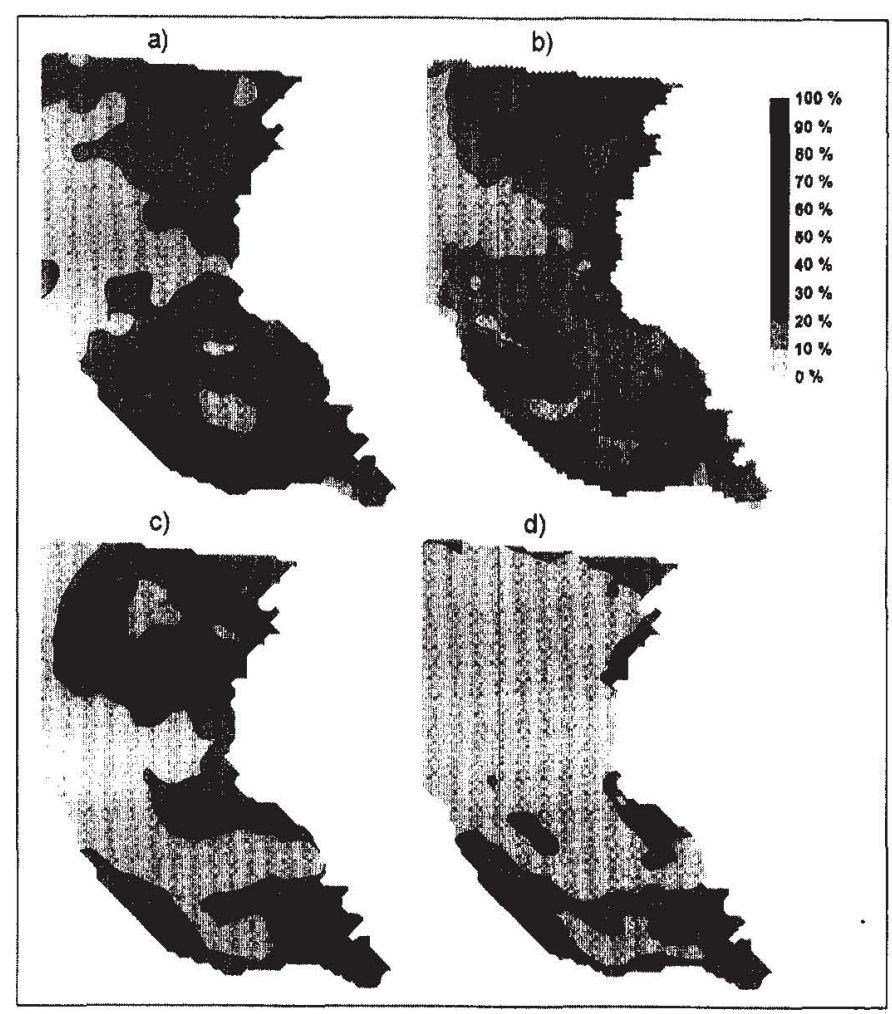

Figure 6. Spatial distribution of transmissivity CV: (a) large cells, measured heads; (b) small cells, measured heads; (c) large cells, kriged heads; (d) small cells, kriged heads.

heads and flow rates through the coefficient of variation (CV). The $\mathrm{CV}$ is the ratio between the standard deviation and the mean of the values. The smaller the $\mathrm{CV}$, the less influential the initial position and the more reliable the results. Figure 6 illustrates the spatial variation of the $\mathrm{CV}$ for the transmissivities and Table 2 summarizes the results for the transmissivities, heads, and spring flow rates. The average CVs of the natural logarithm of the transmissivities are higher than those of the heads due to the fact that, contrary to the transmissivities, the heads were constrained by measured values. The CVs of the natural logarithm of the transmissivities decrease when the number of calibrated parameters decreases (from small to large cells) and when using kriged reference heads. The highest level of uncertainty for transmissivities is therefore associated with the scenario using small cells and measured heads. The transmissivities are less reliable along the eastern border, south of the springs and north of the Bonnieure River, where the measured heads were markedly heterogeneous. The highest $C V$ values for simulated heads are found with the small cells-interpolated heads scenario in which the maximum CVs are along the eastern border (figure not shown). Simulated heads are therefore uncertain in this area, whereas they are relatively reliable elsewhere. The CVs of simulated spring flow rates are low, indicating that this result is reliable. They decrease when using interpolated heads and, contrary to the CVs of the transmissivities and the heads, they also decrease when using small cells. The optimal orientation is the one minimizing the square difference between the measured and the simulated heads. It varies with cell size and with reference heads (Table 2 ). The best orientation appears to be a function of both the position of the available heads and of the regional hydraulic gradients.
Table 2

Coefficients of Variation of Local Transmissivities ( $T$ ) and Local Heads (h) Obtained by Rotation of the Initial Parameter Mesh

\begin{tabular}{|llcccc|}
\hline Cell & $\begin{array}{l}\text { Reference } \\
\text { Size }\end{array}$ & $\begin{array}{c}\text { Average CV } \\
\text { of In (T) } \\
(\boldsymbol{\%})\end{array}$ & $\begin{array}{c}\text { Average CV } \\
\text { of h } \\
(\%)\end{array}$ & $\begin{array}{c}\text { CV on Q } \\
\text { Springs } \\
(\%)\end{array}$ & $\begin{array}{c}\text { Optimal } \\
\text { Angle } \\
()^{\circ}\end{array}$ \\
\hline Large & Measured & 15.1 & 3.9 & 4.8 & 80 \\
Large & Kriged & 13.2 & 3.1 & 3.8 & 30 \\
Small & Measured & 19.9 & 5.9 & 3.2 & 35 \\
Small & Kriged & 8.2 & 2.2 & 2.7 & 55 \\
\hline
\end{tabular}

\section{Discussion and Conclusion}

The scenario using interpolated heads and small cells provided the lowest head residual. However, in this case, the mesh refinement was not performed down to the computation mesh cell size. This is an indication that, in the area studied, the use of small cells with interpolated heads is superfluous. On the other hand, the scenarios using interpolated heads, with large and small cells, generated the most stable and reliable results regarding the rotation of the initial parameter mesh. Overall, the interpolated heads yielded results comparable to those obtained with the measured heads. Interpolated heads should be used when a limited number of head measurements are available or when the heads are not evenly distributed over the aquifer, which is often the case in field studies. However, if the head field is in reality irregular, the use of smoothed interpolated heads, although they would provide stability to the procedure, might not yield realistic results. The scenario using small cells and measured heads generated a highly heterogeneous transmissivity field, probably because of an overparameterization of the problem due to the large number of cells in relation to the number of measured heads. The calibrated transmissivities and simulated heads of this scenario proved to be less reliable overall, and calibration time was much longer. This result underlines the necessity of verifying the influence of cell size on the calibration results. The simulated river/aquifer exchanges were different for measured and interpolated heads but could not be verified due to a lack of data. The calibrated imposed fluxes could not be verified either. The two scenarios using large cells seemed to be the most realistic and easily implemented, but more field measurements would be required to identify the best one.

The results show that inverse modeling and an equivalent porous media can be used to determine transmissivities in a karst aquifer. In a moderately karstified environment such as the area under study, the heads contain sufficient information to be used in the calibration of the model to identify hydraulic properties. These heads provide a reliable transmissivity field that is consistent with the different field-measured transmissivity values. Such good results may not have been attained if more limited head measurements had been used in the calibration. The calibration results also show that this aquifer behaves on the whole like an equivalent porous media with little karstification. At the regional scale and in a steady-state simulation, a more complex representation including the dual component of flow in the fractured matrix and the dissolution channels is not required to simulate ground water flow. However, in a transient-state simulation of ground water flow, the dual component of flow could be sufficiently important to require representation. Solute transport modeling may also require the representation of both fractures and dissolution channels. In a 
more karstified environment, the use of inverse modeling with an equivalent porous media might be inappropriate because of nondarcian flow conditions and because of more significant discontinuities in the measured heads. Other modeling choices should also be evaluated for different karstic environments.

The selected inverse modeling approach proved satisfactory. It was easily implemented and required almost no subjective user intervention. The calculations were relatively short, requiring a few minutes with the large cells and about one hour with the small cells. The downscaling parameterization method identified consistent transmissivity fields without any prior knowledge of the spatial distribution of this parameter. It is possible that this method would not be as suitable in a karst aquifer, where there are highly transmissive channels. In this case, long and narrow zones of high transmissivity elements would better represent the channels, while the fractured aquifer would require larger zones. This variation in cell sizes within the model is not possible with the downscaling parameterization.

In the area studied, inverse modeling proved to be a valuable tool for calibrating ground water flow. This method can be useful in a study of the aquifer aimed at better ground water management because it is relatively objective, contrary to manual calibration, and can be rapidly implemented. It provides hydraulic parameters that can later be used to investigate alternative management practices (modifying pumping rates, partly blocking water losses from rivers, etc.).

\section{Acknowledgments}

This research was supported by the Conseil General de la Charente (France) and the French Ministry of Foreign Affairs. The authors would like to thank Mété-France, the DIREN, the Conseil Général de la Charente, and the BRGM for providing data.

\section{References}

Angelini, P., and W. Dragoni. 1997. The problem of modeling limestone springs: The case of Bagnara (North Apennines, Italy). Ground Water 35, no. 4: 612-618.

Atkinson, T.C. 1977. Diffuse flow and conduit flow in limestone terrain in the Mendip Hills, Somerset (Great Britain). Journal of Hydrology 35: 93-110.

Blaschke, A.P., and G. Blöschl. 1992. Defining pre- and post-processing environment for groundwater modelling. In Proceedings of HYDROCOMP'92, Budapest, Hungary, May 25-29, 383-389. Swindon, Wiltshire, UK: Water Resources Research Center.

Byrd, R.H., P. Lu, J. Nocedal, and C. Zhu. 1995. A limited memory algorithm for bound constrained optimization. SIAM Journal on Scientific Computing 16, no. 5: 1190-1208.

Chardigny, E., R. Mose, P. Ackerer, P. Siegel, and F. Mehreb. 1996. Groundwater flow parameter identification using downscaling parameterization: A field study. In Calibration and Reliability Modelling. Proceedings of the ModelCARE96 Conference, Golden, Colorado, Sept. 1996, ed. K. Kovar and P. Van Der Heijde, 137-145. IAHS Publ. No. 237. Wallingford, Oxfordshire, UK: IAHS.

Chavent, G. 1974. Identification of functional parameters in partial differential equations. In Identification of Parameters in Distributed Systems, ed. R.E. Goodson and M. Polis, 31-48. New York: American Society of Mechanical Engineers.
Delhomme, J.P. 1976. Kriging in the hydrosciences. Advances in Water Resources 1, no. 5: 251-266.

Estrela, T., and A. Sahuquillo. 1997. Modeling the response of a karstic spring at Arteta Aquifer in Spain. Ground Water 35, no 1: 18-24.

Ford, D., and P. Williams. 1989. Karst Geomorphology and Hydrology. London: Chapman \& Hall.

Hydro-Invest. 1994. Levé piézométrique sur le grand karst de La Rochefoucauld. Campagne de hautes eaux, mars 1994. Etude réalisée pour le Conseil Général de la Charente. Report 94060208. Argoulême, France.

Jeannin, P.Y., and A.D. Grasso. 1995. Estimation des infiltrations efficaces journalières sur le bassin karstique de la Milandrine (Ajoie, JU, Suisse). Bulletin d'Hydrogéologie (Université de Neuchâtel) 1995, no. 16: 83-93.

Kresic, N., N. Kukuric, and M. Zlokilica. 1990. Numerical versus stochastic modelling of water balance and minimum discharge of a karst hydrogeological system. In Hydrological Processes in Karst Terranes, Antalya, Turky, Oct. 1990, 253-259. IAHS Publ. No. 207, ed. G. Günay, A.I. Johnson, and W. Back. Wallingford, Oxfordshire, UK: IAHS.

Larocque, M., A. Mangin, M. Razack, and O. Banton. 1998. Contribution of correlation and spectral analyses to the regional study of a large karst aquifer (Charente, France). Journal of Hydrology 205: 217-231.

Mangin, A. 1984. Pour une meilleure connaissance des systèmes hydrologiques à partir des analyses corrélatoire et spectrale. Journal of Hydrology 67: 25-43.

Poeter, E.P., and M.C. Hill. 1997. Inverse models: A necessary next step in ground water modeling. Ground Water 35, no. 2: 250-260.

Pulido-Bosch, A., and A. Padilla-Benitez. 1988. Deux exemples de modélisation d'aquifères karstiques espagnols. Hydrogéologie 1988, no. 4: $281-290$.

Quelennec, R.E., J.C. Sauret, M. Séguin, and J. Vouve. 1971. Les résurgences de la Touvre. Etude préliminaire. In Proceedings of the Colloque d'Hydrologie en Pays Calcaire, Besançon, France, Oct. 1971, 197-254. Université de Besançon, Besançon, France.

Rouiller, D. 1987. Etude des systèmes karstiques de la Touvre et de la Lèche (Angoulême, France). Géologie-HydrodynamiqueHydrochimie. Ph.D. diss., Université des Sciences d'Avignon, France.

Siegel, P. 1995. Transfert de masse en milieux poreux fortement hétérogènes. Modélisation et estimation de paramètres par les éléments finis mixtes hybrides et discontinus. Ph.D. diss., Université Louis Pasteur de Strasbourg (Institut de Mécanique des Fluides), France.

Siegel, P., A.P. Blaschke, and P. Ackerer. 1996. Automatic calibration of groundwater flow parameters for an unconfined aquifer northeast of Vienna. In Calibration and Reliability Modelling. Proceedings of the ModelCARE96 Conference, Golden, Colorado, Sept. 1996, 53-60. IAHS Publ. No. 237. Wallingford, Oxfordshire, UK: IAHS.

White, W.B. 1969. Conceptual models for carbonate aquifers. Ground Water 7, no. 1: 15-21.

Yeh, W.W.G. 1986. Review of parameter identification procedures in groundwater hydrology: The inverse problem. Water Resources Research 22, no. 2: 95-108.

Yeh, T.-C. J., and P.A. Mock. 1996. A structured approach for calibrating steady-state ground water flow models. Ground Water 34, no. 3: $444-450$.

Zhang, Y.K., and E.W. Bai. 1996. Simulation of spring discharge from a limestone aquifer in northeastern Iowa with an identification scheme. In Calibration and Reliability Modeling. Proceedings of the ModelCARE96 Conference, Golden, Colorado, Sept, 1996, 31-40. IAHS Publ. No. 237. Wallingford, Oxfordshire, UK: IAHS. 